\title{
Rasio Neutrofil-Limfosit pada Covid-19; Sebuah tinjauan literatur
}

\author{
Devinqa Adhimah Amanda \\ Fakultas Kedokteran, Universitas Sumatera Utara \\ Email: devinqaaa@yahoo.co.id
}

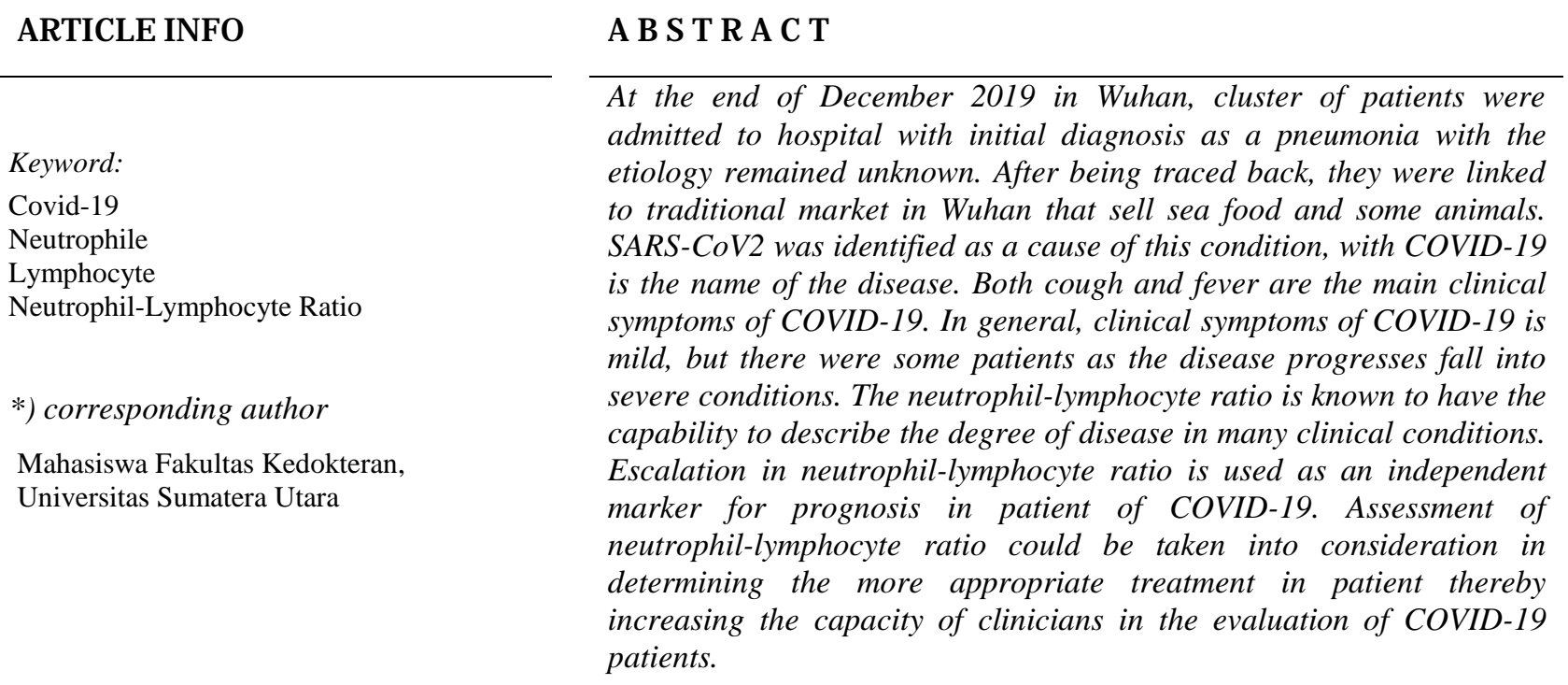

This is an open access article under the CC-BY-SA license.

\section{PENDAHULUAN}

Pada akhir bulan Desember 2019 di Wuhan, didapati adanya sekelompok pasien dengan gejala respirasi yang dibawa ke rumah sakit dengan diagnosis awal berupa pneumonia disertai dengan etiologi yang belum diketahui. Pasien-pasien tersebut setelah ditelusuri kembali masingmasing saling memiliki keterkaitan dengan pasar tradisional di Wuhan, Provinsi Hubei, yang menjual makanan laut dan beberapa satwa seperti unggas, kelelawar dan ular. Setelah diidentifikasi lebih lanjut ditemukan bahwa SARS-CoV2 merupakan penyebabnya, kelompok Coronavirus jenis baru. Penyakit ini diberi nama oleh badan kesehatan dunia, WHO (World Health Organization), sebagai COVID-19 (COrona-VIrus-Disease-2019) (Rothan dan Byrareddy, 2020; Wang et al, 2020; Yuliana, 2020).

Pada tanggal 30 Januari 2020, WHO (World Health Organization) mendeklarasikan adanya darurat kesehatan global yang diakibatkan oleh SARS-CoV2. Oleh karena progresifitas penyakit ini semakin cepat dan jumlah pasien yang terpapar semakin banyak, semenjak 11 Maret 2020, oleh WHO keadaan darurat kesehatan global ini ditetapkan menjadi sebuah pandemik (Qin et al, 2020). 
Sebelumnya juga terjadi wabah yang diakibatkan oleh Coronavirus yaitu Severe Acute Respiratory Syndrome (SARS)-CoV dan Middle East Respiratory Syndome (MERS)-CoV. (Xia et al, 2020)

Demam dan batuk adalah gejala utama dari COVID-19. Sebagian besar pasien yang terinfeksi COVID-19 memiliki gejala klinis yang ringan. Gejala sedang-berat dapat berprogresi secara cepat menjadi keadaan yang lebih buruk seperti gagal pernafasan akut, sindroma distres pernafasan akut, asidosis metabolik, koagulopati, dan syok sepsis. (Liu et al., 2020)

Diperlukannya identifikasi awal untuk memprediksi kondisi pasien yang berisiko mengalami perburukan gejala menjadi lebih berat. Pemeriksaan laboratorium yang sederhana seperti pengukuran rasio neutrofil-limfosit diketahui dapat digunakan sebagai faktor untuk menentukan prognosis dari pasien dalam berbagai situasi klinis (Lee et al, 2020). Peningkatan rasio neutrofillimfosit diketahui berhubungan dengan keparahan dari suatu penyakit dan dapat dipertimbangkan sebagai biomarker yang independen untuk mengindikasi outcome yang buruk. Pada ulasan artikel ini bertujuan untuk melihat apakah ada peran dari rasio neutrofil-limfosit pada penanganan COVID19. (Yang et al, 2020)

\section{METODE}

Sebuah tinjauan literatur mengenai kasus emerging yang sedang dihadapi global, sumber didapatkan dari data google cendikia, PubMed, WHO, menggunakan kata kunci: COVID-19, neutrophil, lymphocyte, NLR. Data-data yang dikumpulkan kemudian dievaluasi kembali dan dituliskan dalam suatu bentuk tulisan ulasan.

\section{HASIL DAN PEMBAHASAN}

Sejak 31 Desember 2019 sampai 30 Juni 2020, jumlah kasus COVID-19 yang tercatat sebesar 10.273.001 di seluruh dunia disertai dengan total kematian sebesar 505.295 jiwa, presentase angka mortalitas kasus di seluruh dunia sampai pada 30 Juni 2020 adalah 4,91\%. Data di Indonesia sendiri sudah tercatat sampai 55.092 jiwa yang terdampak dengan total kematian sebesar 2.805 jiwa. (European Centre for Disease Prevention Control, 2020)

Angka mortalitas pada COVID-19 lebih rendah daripada yang diakibatkan oleh jenis coronavirus yang lain, seperti SARS-CoV dan MERS. Virus SARS-CoV menyebar secara global sampai sekitar 30 negara, menginfeksi 8.098 manusia dan membunuh 774 jiwa dari November 2002 sampai Juli 2003, dan juga lebih rendah dari penyakit yang diakibatkan MERS-CoV yang menyebar pada 27 negara, menginfeksi 2.494 manusia dan membunuh 858 pasien dari September 2012 sampai September 2019, angka mortalitas SARS CoV dan MERS-CoV masing-masing sebesar 9.6\% dan 34.4\%. (Li et al, 2020). Walaupun angka mortalitas saat ini pada SARS-CoV2 lebih rendah dibandingkan dengan SARS-CoV dan MERS-CoV, SARS-CoV2 memiliki tingkat penularan yang pesat. Publik harus waspada mengenai perkembangan dari penyakit ini (Wang et al, 2020).

Masa inkubasi pada COVID-19 bervariasi antara 2 hari sampai 2 minggu setelah terjadi paparan (Carlos et al., 2020). Menurut penelitin yang dilakukan Li et al didapati bahwa gejala dari infeksi COVID-19 muncul setelah periode inkubasi sekitar 5.2 hari (Li et al, 2020). Pada penelitian ini juga didapati bahwa usia lebih lanjut memiliki progresifitas yang lebih cepat menuju kondisi yang buruk, terbukti dari data bahwa pada angka median, lamanya durasi dari awal timbul gejala sampai kematian pada usia lebih dari 70 tahun lebih singkat (11.5 hari) dibandingkan dengan yang lebih muda (20 hari). (Wang et al, 2020)

Demam dan batuk merupakan dua gejala yang paling banyak dialami. Banyak pasien yang menunjukkan gejala yang ringan dan sebagian dari itu mempunyai prognosis yang buruk. Sampai saat ini, ada beberapa pasien COVID-19 yang mengalami perburukan menjadi pneumonia berat, 
edema pulmo, sindroma akut respiratori atau gagal organ multipel dan akhirnya meninggal (Yang et $a l, 2020)$. Melihat adanya penyebaran yang cepat dan kerusakan yang serius pada COVID-19, hal ini merupakan penting untuk secara kontinu meningkatkan kemampuan diagnosis klinis dan studistudi mengenai pengobatannya (Yang et al, 2020).

Terdapat beberapa bukti yang menunjukkan bahwa pada pasien COVID-19 dengan gejala berat dapat mengalami respon imun yang terganggu, hal ini dapat menyebabkan perkembangan dari hiperinflamasi dari virus. Oleh karen itu, pasien-pasien dengan gejala COVID-19 yang berat harus diperiksa parameter laboratorium untuk penanda hiperinflamasi untuk memperbaiki angka mortalitas (Lagunas-rangel, 2020).

Inflamasi disebabkan salah satunya oleh karena infeksi. Respon inflamasi yang berat berkontribusi pada respon imun adaptif yang lemah, dengan demikian hal ini menyebabkan imbalans dari respon imun. Oleh karena itu, biomarker yang berada di sirkulasi dapat mempresentasikan status inflamasi dan imun yang dapat berguna sebagai predikor yang potensial dalam prognosis dari pasien COVID-19. (Yang et al, 2020)

Rasio neutrofil-limfosit merupakan salah satu indikator dari adanya respon inflamasi sistematis yang secara luas digunakan sebagai penentu prognosis dari pasien dengan pneumonia oleh karena virus. Peningkatan rasio neutrofil-limfosit dapat merefleksikan proses inflamasi yang meningkat dan dapat berkaitan dengan prognosis yang buruk (Lagunas-rangel, 2020). Peningkatan rasio neutrofil-limfosit dan usia secara signifikan berhubungan dengan keparahan dari penyakit. Peningkatan usia dan rasio neutrofil-limfosit dapat dipertimbangkan sebagai biomarker yang independen dalam mengindikasikan outcome yang buruk (Yang et al, 2020).

Neutrofil merupakan komponen utama dari leukosit yang secara aktif bermigrasi menuju sistem atau organ imunitas. Neutrofil mengeluarkan ROS (Reactive Oxygen Species) dalam jumlah besar yang menginduksi kerusakan dari DNA sel dan menyebabkan virus bebas keluar dari sel. Kemudian ADCC (Antibody-Dependent Cell-Mediated Cell) dapat langsung membunuh virus secara langsung dan memicu imunitas humoral. Neutrofil dapat dipicu oleh faktor-faktor inflamasi yang berkaitan dengan virus, seperti interleukin-6, interleukin-8, faktor nekrosis tumor, granulocyte colony stimulating factor, dan interferon-gamma factors, yang dihasilkan oleh limfosit dan sel endothel. Di samping itu, respon imun manusia yang diakibatkan oleh virus terutama bergantung pada limfosit, dimana inflamasi yang sistemik secara signifikan menekan imunitas seluler, dimana secara signifikan menurunkan kadar CD4+ limfosit $\mathrm{T}$ dan meningkatkan CD8+ supresor limfosit $\mathrm{T}$. Oleh karena itu, inflamasi yang dipicu oleh karena virus meningkatkan rasio neutrofil-limfosit. Peningkatan rasio neutrophil-limfosit memicu progresivitas COVID-19 (Yang et al, 2020)

Tingkat keparahan dari COVID-19 dinilai berdasarkan the Fifth Revised Trial Version of the Novel Coronavirus Pneumonia Diagnosis and Treatment Guidance. Bagi yang memenuhi kriteria sebagai berikut, didefinisikan sebagai tipe yang berat: 1 . Distres pernafasan dengan laju napas lebih dari 30 kali per menit; 2. Saturasi oksigen $\leq 93 \%$ dalam keadaan istirahat; 3. Tekanan parsial oksigen darah arteri (PaO2) / konsentrasi oksigen (FiO2) $\leq 300 \mathrm{mmHg}$ (Qin et al, 2020). Beberapa kasus yang berat memiliki komorbid, seperti hipertensi, diabetes, gagal jantung dan insufisiensi renal (Yang et al, 2020).

Tabel 1

Rekomendasi mengenai penanganan pada pasien COVID-19 berdasarkan usia dan pemeriksaan laboratorium berupa rasio neutrofil-limfosit.

\begin{tabular}{lll}
\hline Pasien COVID-19 & \multicolumn{1}{c}{ Rasio Neutrofil-Limfosit $<\mathbf{3 . 1 3}$} & \multicolumn{1}{c}{ Rasio Neutrofil-Limfosit $\geq \mathbf{3 . 1 3}$} \\
\hline Usia $<50$ tahun & Tidak berisiko: & Risiko ringan: \\
& Isolasi di rumah & Isolasi di bangsal umum \\
\hline Usia $\geq \mathbf{5 0}$ tahun & Risiko sedang: & Risiko berat: \\
& Isolasi di bangsal umum dengan pemantauan & Pindah ke ICU dengan peralatan pendukung \\
& pada respirasi dan perawatan suportif & pernafasan invasif \\
\hline
\end{tabular}


Pada penelitian yang dilakukan oleh Liu et al, sebanyak 61 pasien dalam kurun waktu 13 Januari sampai 31 Januari 2020 dilakukan pemantauan. Pada pasien dikelompokkan berdasarkan usia (usia $<50$ tahun; usia $\geq 50$ tahun) dan rasio neutrofil-limfosit (risiko rendah: $<3.13$; risiko tinggi $\geq 3.13$ ). Analysis menggunakan Kaplan-Meier menunjukkan terdapat perbedaan yang signifikan pada kedua kelompok tersebut $(\mathrm{p}=0.00028$ dan $\mathrm{p}=0.0005)$. Kemudian pasien distratifikasi untuk derajat beratnya penyakit, berdasarkan usia dan rasio neutrofil-limfosit (kelompok 1: usia $<50$ tahun dan rasio neutrofil-limfosit $<3.13$; kelompok 2: usia $<50$ tahun dan rasio neutrofil-limfosit $\geq 3.13$; kelompok 3: usia $\geq 50$ tahun dan rasio neutrofil-limfosit $<3.13$; kelompok 4: usia $\geq 50$ tahun dan rasio neutrofil-limfosit $\geq 3.13$ ). Didapatkan bahwa tidak ada pasien dengan gejala yang berat pada kelompok 1 dan 2. Terdapat 1 kasus pasien dengan gejala berat di kelompok 3, dan 7 kasus gejala berat di kelompok 4. Dapat disimpulkan bahwa berdasarkan derajat berat dari penyakit terdapat perbedaan yang signifikan untuk kelompok 3 dan $4(\mathrm{p}=0.0195)$. (Liu et al, 2020)

Berdasarkan hasil ini direkomendasikan penanganan yang lebih lanjut pada pasien berdasarkan kedua parameter tersebut. Pasien dengan usia $<50$ tahun dan rasio neutrofil-limfosit $<$ 3.13 dapat dilakukan isolasi di rumah. Pasien dengan usia $<50$ tahun dan rasio neutrofil-limfosit $\geq$ dimana merupakan risiko rendah perlu dilakukan isolasi di bangsal umum. Pasien dengan usia $\geq 50$ tahun dan rasio neutrofil-limfosit $<3.13$ dimana merupakan risiko sedang, perlu dilakukan isolasi di bangsal dengan pemantauan pada kondisi klinis dan perawatan suportif. Pasien dengan usia $\geq 50$ tahun dan rasio neutrofil-limfosit $\geq 3.13$ merupakan kelompok risiko tinggi perlu dirawat di ruangan intensif dengan peralatan pendukung pernafasan invasif (Liu et al, 2020).

Pengukuran rasio neutrofil-limfosit diperlukan untuk mengukur stratifikasi risiko, menilai prognosis, peringatan untuk tanda awal dari gejala COVID-19 yang berat. Pengukuran rasio neutrofil-limfosit juga merupakan pemeriksaan pemeriksaan darah yang sederhana sehingga mudah diaplikasikan dalam praktik klinis sehari-hari, hemat dalam pembiayaan, dan berguna sebagai penilaian dan pertimbangan untuk menangain pasien (Lagunas-rangel, 2020).

\section{SIMPULAN DAN SARAN}

Peningkatan rasio neutrofil-limfosit dapat digunakan sebagai sebagai peringatan untuk tanda awal dari gejala COVID-19 yang berat serta sebagai penanda prognosis yang independen pada pasien COVID-19 (Xia et al, 2020). Penilaian dari rasio neutrofil-limfosit dapat meningkatan kapasitas evaluasi untuk pasien COVID-19. Oleh karena itu, penggunaan rasio neutrofil-limfosit disertai dengan pertimbangan usia dapat direkomendasikan untuk menilai prognosis, mengevaluasi derajat penyakit berdasarkan gejala klinis dari pasien, dan menentukan penanganan yang tepat pada pasien dengan COVID-19 (Yang et al, 2020).

\section{DAFTAR PUSTAKA}

Carlos, W. G., Dela, C. C., Cao, B., Pasnick, S., \& Jamil, S. (2020). Novel Wuhan (2019-nCoV) Coronavirus. American journal of respiratory and critical care medicine, 201(4), P7. doi: $\underline{10.1164 / \mathrm{rccm} .2014 \mathrm{P} 7}$

European Centre for Disease Prevention Control. COVID-19 situation update worldwide, as of 30 June 2020. Accessed on 30 June 2020. Available at https://www.ecdc.europa.eu/en/geographical-distribution-2019-ncov-cases

Lagunas-Rangel, F. A. (2020). Neutrophil-to-lymphocyte ratio and lymphocyte-to-C-reactive protein ratio in patients with severe coronavirus disease 2019 (COVID-19): A meta-analysis. Journal of medical virology. doi: https://doi.org/10.1002/jmv.25819 
Lee, J. S., Kim, N. Y., Na, S. H., Youn, Y. H., \& Shin, C. S. (2018). Reference values of neutrophil-lymphocyte ratio, lymphocyte-monocyte ratio, platelet-lymphocyte ratio, and mean platelet volume in healthy adults in South Korea. Medicine, 97(26). doi: $\underline{10.1097 / M D .0000000000011138}$

Li, Q., Guan, X., Wu, P., Wang, X., Zhou, L., Tong, Y., ... \& Xing, X. (2020). Early transmission dynamics in Wuhan, China, of novel coronavirus-infected pneumonia. New England Journal of Medicine. doi: 10.1056/NEJMoa2001316

Liu, J., Liu, Y., Xiang, P., Pu, L., Xiong, H., Li, C., Song, M.. et al., (2020). Neutrophil-tolymphocyte ratio predicts severe illness patients with 2019 novel coronavirus in the early stage. MedRxiv. doi: https://doi.org/10.1101/2020.02.10.20021584

Qin, C., Zhou, L., Hu, Z., Zhang, S., Yang, S., Tao, Y., ... \& Tian, D. S. (2020). Dysregulation of immune response in patients with COVID-19 in Wuhan, China. Clinical Infectious Diseases. doi: https://doi.org/10.1093/cid/ciaa248

Rothan, H. A., \& Byrareddy, S. N. (2020). The epidemiology and pathogenesis of coronavirus disease (COVID-19) outbreak. Journal of autoimmunity, 102433. doi: https://doi.org/10.1016/j.jaut.2020.102433

Wang, W., Tang, J., \& Wei, F. (2020). Updated understanding of the outbreak of 2019 novel coronavirus (2019-nCoV) in Wuhan, China. Journal of medical virology, 92(4), 441-447. doi: https://doi.org/10.1002/jmv.25689

WHO. Middle East Respiratory Syndrome Coronavirus (MERS-CoV). Accessed on 28 June 2020. Available at https://www.who.int/emergencies/mers-cov/en/

WHO. Summary of probable SARS cases with onset of illness from 1 November 2002 to 31 July 2003. Released on 26 Sep 2003. Available at https://www.who.int/csr/sars/country/table2004_04_21/en/

Xia, X., Wen, M., Zhan, S., He, J., \& Chen, W. (2020). An increased neutrophil/lymphocyte ratio is an early warning signal of severe COVID-19. Nan fang yi ke da xue xue bao= Journal of Southern Medical University, 40(3), 333. doi: 10.12122/j.issn.1673-4254.2020.03.06

Yang, A. P., Liu, J., Tao, W., \& Li, H. M. (2020). The diagnostic and predictive role of NLR, dNLR and PLR in COVID-19 patients. International immunopharmacology, 106504. doi: https://doi.org/10.1016/j.intimp.2020.106504

Yuliana, Y. (2020). Corona virus diseases (Covid-19): Sebuah tinjauan literatur. Wellness And $\begin{array}{llllll}\text { Healthy } & \text { Magazine, } & 2(1), & 187 & - & 192 .\end{array}$ from https://wellness.journalpress.id/wellness/article/view/21026 